\title{
PENGARUH REGULASI ECO LABELLING DI UNI EROPA TERHADAP REGULASI EKSPOR PRODUK KAYU DI INDONESIA
}

\author{
Masitha Tismananda Kumala \\ Fakultas Hukum Universitas Airlangga \\ e-mail:masitha@gmail.com
}

\begin{abstract}
ABSTRAK
Uni Eropa mengeluarkan suatu regulasi terkait Eco Labelling terhadap semua barang dan jasa yang ada di pasar Uni Eropa, tidak terkecuali produk kayu. Regulasi tersebut diberlakukan terhadap produk kayu di negara-negara Uni Eropa maupun produk kayu yang di impor oleh negara-negara anggota Uni Eropa. Sistem Eco Label pertama kali diperkenalkan di Uni Eropa melalui Council Regulation (EEC) No. 880 Tahun 1992. Regulasi ini mengatur mengenai pemberian Eco Label terhadap berbagai produk, termasuk produk kayu. Dengan adanya regulasi tersebut, mau tidak mau membuat negara yang mengekspor produknya ke Uni Eropa harus memperhatikan ketentuan tersebut, tidak terkecuali dengan Indonesia. Banyak produsen Indonesia yang mengekspor produk kayu ke negara-negara Uni Eropa. Sehingga pada saat itu sangat dibutuhkan sekali pengaturan mengenai Eco Label di Indonesia. Selain itu, yang terpenting adalah dibutuhkannya lembaga yang mengeluarkan sertifikat Eco Label agar produk kayu asal Indonesia dapat menembus pasar Uni Eropa. Hal ini disebabkan banyaknya produsen Indonesia yang mengekspor produk kayu di negara-negara Uni Eropa. Kebutuhan Indonesia akan aturan dan lembaga yang terkait dengan Eco Label dikarenakan adanya globalisasi dalam perdagangan internasional. Pada akhirnya disadari atau tidak, dengan adanya globalisasi, suatu aturan hukum di satu negara akan mempengaruhi aturan hukum di negara lain.
\end{abstract}

Kata Kunci: Eco Label, ekspor, impor, perdagangan internasional, globalisasi.

\begin{abstract}
The European Union issued an Eco Labelling regulations related to all the goods and services in the EU market, including timber products. The regulation is applicable to timber products in state member of the European Union and timber product which are imported by state member of the European Union. Eco Label system was first introduced in the EU by Council Regulation (EEC) No. 880 of 1992. The regulation set regarding Eco Label Award to a variety of products, including timber products. With the existence of these regulations, inevitably make states who export their products to the EU must pay attention to these provisions, including with Indonesia. Many Indonesian producers that export timber products to the state member of EU. So it is needed setting regulation about Eco Label in Indonesia. In addition, it is requirement to establish the institution that issued the Eco Label certificate so that Indonesian timber products can get into the EU market. This is due to the many Indonesian producers were exporting timber products in state member of the European Union. Indonesia's requirement for regulations and institutions associated with Eco Label are caused by the globalization of international trade. In the end we realize it or not, with the globalization, a rule of law in one country will affect the rule of law in another country. Keywords: Eco Label, export, import, international trade, globalization.
\end{abstract}

\section{PENDAHULUAN}

Adanya World Trade Organization (selanjutnya disingkat WTO) adalah untuk mencapai tujuan tertentu, yaitu pengurangan tariff secara substansial, pengurangan hambatan-hambatan non tariff terhadap perdagangan, dan untuk menghilangkan perlakuan diskriminatif dalam perdagangan internasional. ${ }^{1} \mathrm{Hal}$ tersebut berarti tujuan WTO untuk menghilangkan

\footnotetext{
${ }^{1}$ Hata, Perdagangan Internasional dalam Sistem GATT dan WTO (Aspek-aspek Hukum dan Non Hukum), Refika Aditama, Bandung, 2006, h. 88.
} 
hambatan-hambatan yang ada dalam perdagangan internasional.

Hambatan dalam perdagangan internasional haruslah dikurangi atau bahkan dihilangkan agar arus perdagangan internasional menjadi lancar. Semula negara-negara di dunia cenderung memberikan hambatan-hambatan terhadap produk import yang akan masuk ke negaranya, baik berupa tariff maupun non tariff barriers. Hal ini dilakukan untuk memproteksi produsen dalam negeri. Sikap proteksi yang dilakukan oleh negara inilah yang akan menghambat arus perdagangan internasional.

Richard Rosecrance memaparkan betapa besarnya kekuatan yang dapat diwujudkan suatu bangsa melalui kemampuan dagangnya. Kegiatan perdagangan mampu menggantikan ekspansi wilayah dan perang militer sebagai kunci pokok menuju kesejahteraan dan pencapaian kekuasaan internasional. Disimpulkannya bahwa manfaat perdagangan dan kerjasama internaisonal, dewasa ini jauh melampaui manfaat persaingan militer dan perluasan wilayah. ${ }^{2}$

Resiko yang akan terjadi apabila arus perdagangan internasional tidak lancar adalah tidak adanya persaingan dalam pasar. Pihak yang dirugikan dalam hal ini adalah konsumen, karena konsumen susah untuk mendapatkan suatu barang yang murah sekaligus berkualitas bagus. Di samping itu, negara juga menyadari bahwa perdagangan adalah satusatunya cara untuk pembangunan ekonomi mereka, karena untuk memperoleh kemandirian dan kontrol terhadap ekonomi internasional, negara harus mengadakan hubungan-hubungan perdagangan yang mapan dengan negara lainnya. ${ }^{3}$

Dengan adanya kesadaran dari negara-negara tersebut, maka hambatan-hambatan yang dibuat oleh negara mulai menghilang. Proses penghilangan hambatan inilah yang disebut dengan globalisasi.

Menurut Ami Chua, globalisasi pada hakikatnya adalah suatu proses transformasi sosial yang akan membawa kondisi umat manusia yang berbeda-beda dan terpencar-pencar di banyak wilayah di dunia ini menjadi satu kondisi tunggal yang tidak mengenal

${ }^{2}$ Richard Rosecrance, The Rise of the Trading State (Terjemahan Budiono Kusumohamidjojo dengan judul Kebangkitan Negara Dagang), Gramedia Pustaka Utama, Jakarta, 1991, h. ix, dikutip dari ibid., h. 1.

${ }^{3}$ Huala Adolf, Hukum Perdagangan Internasional, Cetakan ke-5, Rajagrafindo, Jakarta, 2013, h. 19. lagi batas-batas wilayah. ${ }^{4}$ Globalisasi tidak hanya ada dalam bidang ekonomi, namun juga dalam bidang politik, budaya, dan hukum. Disadari atau tidak, pengaruh globalisasi terhadap hukum membuat suatu hukum di satu negara dapat mempengaruhi hukum di negara lain. Hal tersebut dikarenakan negara-negara di dunia sudah saling terkait dan saling membutuhkan satu sama lain. Artinya, hambatan-hambatan di antara negara-negara tersebut semakin terkikis.

Uni Eropa mengeluarkan suatu regulasi terkait Eco Labelling terhadap semua barang dan jasa yang ada di pasar Uni Eropa, tidak terkecuali produk kayu. Regulasi tersebut diberlakukan terhadap produk kayu di negara-negara Uni Eropa maupun produk kayu dari luar negeri yang di ekspor di negara-negara anggota Uni Eropa. Eco Labelling merupakan metode sertifikasi yang terkait dengan lingkungan dan sertifikasi ini dipraktekkan oleh banyak negara di dunia. Eco Label merupakan label yang mengidentifikasi secara keseluruhan, membuktikan preferensi lingkungan dari produk atau jasa dalam produk/kategori layanan tertentu. ${ }^{5}$

Isu Eco Labelling bukan hal yang baru. Program Eco Label pertama kali diperkenalkan di Jerman pada Tahun 1979, yang dikenal dengan nama Blue Angel. Kemudian diikuti oleh negara-negara lain seperti Jepang dengan Ecomark, Taiwan dengan Greenmark, serta Singapura dan Thailand dengan Green label. ${ }^{6}$

Sistem Eco Label pertama kali diperkenalkan di Uni Eropa melalui Council Regulation (yang selanjutnya disingkat EEC) No. 880 Tahun 1992. Regulasi ini mengatur mengenai pemberian Eco Label terhadap berbagai produk, termasuk produk kayu. Dengan adanya regulasi tersebut, mau tidak mau membuat negara yang mengekspor produknya ke Uni Eropa harus memperhatikan ketentuan tersebut, tidak terkecuali dengan Indonesia. Banyak produsen Indonesia yang mengekspor produk kayu ke negara-negara Uni Eropa. Sehingga pada saat itu sangat dibutuhkan sekali pengaturan mengenai Eco Label di Indonesia. Selain itu, yang terpenting adalah dibutuhkannya lembaga yang mengeluarkan

\footnotetext{
${ }^{4}$ Mahendra Putra Kurnia, ed., Ketika Hukum Berhadapan Dengan Globalisasi, UB Press, Malang, 2011, h. 1.

${ }^{5} \mathrm{http}: / / w w w . g l o b a l e c o l a b e l l i n g . n e t / w h a t$ is_ecolabelling/ index.htm, diakses pada tanggal 23 Oktober 2013, pukul 10:19.

6 Suminto, "Kajian Penerapan Ekolabel Produk di Indonesia", Jurnal Standardisasi, Vol. 13, No. 3, Tahun 2011, h. 202 .
} 
sertifikat Eco Label agar produk kayu asal Indonesia dapat menembus pasar Uni Eropa. Hal ini disebabkan banyaknya produsen Indonesia yang mengekspor produk kayu di negara-negara Uni Eropa.

Kebutuhan Indonesia akan aturan dan lembaga yang terkait dengan Eco Label dikarenakan adanya globalisasi dalam perdagangan internasional. Pada akhirnya disadari atau tidak, dengan adanya globalisasi, suatu aturan hukum di satu negara akan mempengaruhi aturan hukum di negara lain.

\section{PERUMUSAN MASALAH}

Regulasi di Uni Eropa terkait Eco Labelling terhadap produk kayu, serta Regulasi di Indonesia sebagai akibat adanya regulasi Eco Labelling di Uni Eropa.

\section{METODE PENELITIAN}

Dalam penelitian di penulisan ini menggunakan tipe penelitian hukum normatif yang mendasarkan pada pendekatan masalah statute approach dan conceptual approach, adapun Konvensi yang dikaji sebagai berikut: Voluntary Partnership Agreement on Forest Law Enforcement Governance and Trade (FlEGT-VPA); Keputusan Menteri Kehutanan No. 4795/Kpts-II/2002 tentang Kriteria dan Indikator Pengelolaan Hutan Alam Produksi Lestari pada Unit Pengelolaan; Council Regulation (EEC) No. 880 Tahun 1992; Regulation (EC) No. 1980 Tahun 2000; Regulation (EC) No. 66 Tahun 2010; dan Regulation (EU) No. 995/2010 of the European Parliament and of the Council (EU Timber Regulation). Sedangkan conceptual approach mengkaji konsep Eco Labelling.

\section{PEMBAHASAN}

\section{Regulasi di Uni Eropa Terkait Eco Labelling Terhadap Produk Kayu}

Eco Labelling pertama kali dikenalkan di Uni Eropa melalui Council Regulation (EEC) No. 880 Tahun 1992 (selanjutnya disingkat Regulation 880 Tahun 1992). Di dalam Article 1 Regulation 880 Tahun 1992, disebutkan bahwa ditetapkannya Eco Labelling ini memiliki dua maksud. Pertama, untuk mempromosikan desain, produksi, pemasaran dan penggunaan produk yang memiliki dampak lingkungan yang lebih sedikit. Yang kedua adalah untuk menyediakan informasi yang lebih baik kepada konsumen terkait dampak lingkungan dari produk.
Dalam Article 4 Regulation 880 Tahun 1992, disebutkan bahwa yang dapat diberi Eco Label adalah produk-produk yang memenuhi tujuan yang ditetapkan dalam Article 1. Hal tersebut berarti produk kayu termasuk dalam produk yang sesuai dengan tujuan yang ada dalam Article 1 karena tentu produk kayu sangat berpengaruh terhadap kelestarian lingkungan karena merupakan hasil dari pengelolaan hutan. Dalam Article 2 Regulation 880 Tahun 1992, di atur bahwa regulasi ini dkecualikan untuk produk makanan, minuman, dan produk farmasi.

Regulation 880 Tahun 1992 diubah oleh Regulation (EC) No. 1980 Tahun 2000 (Selanjutnya disingkat Regulation 1980 Tahun 2000) dengan perubahan bahwa tujuan adanya Eco Label ini adalah mempromosikan produk yang memiliki dampak lingkungan yang lebih sedikit dibandingkan dengan produk lain dalam kelompok produk yang sama dan menyediakan informasi yang akurat dan berbasis ilmiah dan bimbingan atas produk kepada konsumen.

Article 1 angka 2 Regulation 1980 Tahun 2000 mengatur bahwa untuk mengetahui dampak lingkungan dari suatu produk, harus dilakukan identifikasi dan pemeriksaan terhadap interaksi produk dengan lingkungan, termasuk penggunaan energi dan sumber daya alam, selama siklus hidup produk-produk tersebut.

Perubahan lainnya adalah terkait produk yang tidak termasuk dalam ruang lingkup regulasi ini, yang diatur dalam Article 2 angka 5 dengan menambahkan produk yang dikecualikan atas regulasi ini. Produk yang dikecualikan atas regulasi ini adalah produk makanan dan minuman, produk farmasi, dan peralatan medis yang hanya digunakan oleh profesional, atau diresepkan, atau dalam pengawasan profesional medis.

Terdapat perubahan lainnya, yaitu terkait kriteria product group atau kelompok produk yang sama. Regulation 880 Tahun 1992 menetapkan bahwa yang dimaksud dengan product group adalah produk yang memiliki tujuan yang sama dan penggunaan yang ekuivalen. Sedangkan Regulation 1980 Tahun 2000 memberikan kriteria yang lebih rumit seperti prospek produk untuk memasuki pasar, kelayakan teknis dan ekonomi dari penyesuaian yang perlu, potensi untuk perbaikan lingkungan, dampak terhadap lingkungan 
yang signifikan, dan lain-lain. Regulation 1980 Tahun 2000 juga mencabut Regulation 880 Tahun 1992.7

Tahun 2010, di Uni Eropa berlaku regulasi terbaru terkait Eco Labelling, yaitu Regulation (EC) No. 66 Tahun 2010 (selanjutnya disingkat Regulation 66/2010). Dalam Article 2 angka 1 diatur bahwa Regulation 66/2010 berlaku bagi semua produk dan jasa yang didistribusikan, dikonsumsi, atau digunakan dalam pasar Uni Eropa. Artinya adalah bahwa regulasi ini tidak hanya berlaku bagi produk dalam negeri saja, namun juga untuk produk impor. Dalam Article 2 angka 2, lebih lanjut diatur bahwa regulasi ini tidak berlaku bagi produk obat untuk manusia dan hewan, karena telah diatur di regulasi yang lain.

Dalam Article 6 Regulation 66/2010, diatur bahwa Eco Label diberikan dengan mempertimbangkan secara khusus: Dampak barang dan jasa pada perubahan iklim, alam dan keanekaragaman hayati, energi dan sumber daya konsumsi, timbulnya limbah, polusi, emisi dan pelepasan zat berbahaya ke lingkungan; Substitusi bahan berbahaya oleh zat yang lebih aman; Daya tahan dan kegunaan dari produk; Dampak utama terhadap lingkungan, termasuk pada kesehatan dan keselamatan konsumen; Apakah sesuai dengan standar sosial dan etika, seperti standar perburuhan internasional; Dengan mempertimbangkan kriteria yang ditetapkan oleh label lain di tingkat nasional dan daerah; Mengurangi pengujian produk terhadap hewan (animal testing).

\section{Regulasi di Uni Eropa Terkait Kayu}

Komoditas utama hasil hutan adalah kayu. Uni Eropa dikenal sebagai organisasi yang sungguhsungguh menolak adanya penebangan liar atau illegal logging. Oleh karena itu Uni Eropa merasa perlu adanya aturan yang mengatur mengenai kayu/ timber dan produk kayu/timber product. Pada tahun 2010, dibuatlah Regulation (EU) No. 995/2010 of the European Parliament and of the Council atau EU Timber Regulation. Article 4 Timber Regulation melarang masuknya kayu atau produk kayu yang dipanen secara illegal ke pasar Uni Eropa. Kemudian mengenai apa yang dimaksud dengan panen secara illegal telah diatur dalam Article 2 huruf g, yaitu prosen panen yang bertentangan dengan hukum yang

${ }^{7}$ http://europa.eu/legislation_summaries/other/l28020_ en.htm, diakses pada tanggal 21 Oktober 2013. ada di negara tempat di mana kayu atau produk kayu di panen.

Melihat definisi yang diberikan oleh Article 2 huruf g, berarti Timber Regulation tidak hanya berlaku bagi produk lokal Uni Eropa, namun juga untuk produk impor, termasuk kayu dari Indonesia. Dalam Annex Timber Regulation, diatur mengenai jenis kayu atau produk kayu yang masuk dalam ruang lingkup pengaturan Timber Regulation, yaitu: Kayu bakar, berbentuk log, billet, ranting; kayu berbentuk chip atau partikel; serbuk gergaji dan limbah kayu; Kayu dalam bentuk kasar, yaitu kayu yang belum di kupas kulit kayunya atau lapisan terluar kayu; Kereta api dari kayu; Kayu yang di gergaji, di potong, atau di kupas, yang ketebalannya tidak melebihi $6 \mathrm{~mm}$; Papan partikel, Oriented Strand Board (OSB) dan papan semacam itu; Fibreboard yang terbuat dari kayu; Plywood, veneered panels, dan kayu yang dilaminasi semacam itu; Kayu yang dipadatkan, dibentuk blok, lempengan, atau memanjang; Bingkai kayu untuk lukisan, cermin, foto, atau semacamnya; Peti, kotak, krat, drum dan pengemasan semacam itu, dari kayu; kabel-drum kayu; kotak dan papan untuk muatan lainnya, dari kayu; Furniture dari kayu; Bubur kayu dan kertas. Timber Regulation ini tidak meliputi produk daur ulang, dan juga kertas cetak seperti buku, majalah, dan koran. ${ }^{8}$

Untuk mengetahui apakah kayu atau produk kayu tersebut legal, maka Timber Regulation menciptakan sistem uji kelayakan yang diatur dalam Article 6 . Sistem uji kelayakan sebagaimana dimaksud harus mengandung unsur-unsur berikut:

Pertama, Langkah-langkah dan prosedur yang menyediakan akses informasi mengenai pasokan kayu atau produk kayu yang ditempatkan di pasar, berupa: Deskripsi, termasuk nama dagang dan jenis produk serta nama umum dari jenis pohon dan, jika memungkinkan, beserta nama ilmiahnya juga; Negara panen, dan jika diperlukan: wilayah sub-nasional dimana kayu di panen dan konsesi panen; Kuantitas (dinyatakan dalam volume, berat atau jumlah unit); Nama dan alamat importir dan pemasok kayu ke importir apabila ada; Nama dan alamat pedagang kepada siapa kayu dan produk kayu telah disediakan; Dokumen atau informasi lain yang menunjukkan

\footnotetext{
${ }^{8}$ http://ec.europa.eu/environment/forests/timber_regulation. htm, diakses pada tanggal 21 Oktober 2013.
} 
bahwa kayu dan produk kayu tersebut diperoleh sesuai dengan undang-undang yang berlaku.

Kedua, Jaminan kepatuhan terhadap peraturan perundang-undangan yang berlaku, yang dapat berupa sertifikasi atau verifikasi dari negara di mana kayu dan produk kayu di panen.

Dengan melihat ketentuan yang ada di dalam Timber Regulation, maka Indonesia sebagai negara pengekspor hasil kayu ke Uni Eropa perlu untuk membuat suatu regulasi yang mengatur mengenai sertifikasi atau labelling terhadap kayu atau produk kayu yang menyatakan bahwa kayu atau produk kayu tersebut legal, agar arus perdagangan tidak terhambat.

\section{Peraturan Menteri Terkait Eco Labelling Sebagai Akibat Adanya Regulasi Eco Labelling di Uni Eropa}

Terkait pengelolaan hutan, Indonesia memiliki Keputusan Menteri Kehutanan No. 4795/KptsII/2002 tentang Kriteria dan Indikator Pengelolaan Hutan Alam Produksi Lestari pada Unit Pengelolaan. Keputusan menteri ini mengatur mengenai kriteria dan indikator yang perlu diikuti oleh badan usaha yang mendapat Hak Pengusahaan Hutan dan/ atau Ijin Usaha Pemanfaatan Hasil Hutan Kayu di hutan alam. Para pemegang Hak Pengusahaan Hutan dan/atau Ijin Usaha Pemanfaatan Hasil Hutan Kayu untuk melakukan pengelolaan hutan alam produksi lestari. Pengelolaan Hutan Alam Produksi Lestari (PHAPL) adalah strategi dan pelaksanaan kegiatan untuk memproduksi hasil hutan alam yang menjamin kelestarian fungsi produksi, ekologi, sosial dan kepatuhan terhadap regulasi.

Mengenai kriteria dan indikator apa saja yang harus dilaksanakan, termuat dalam lampiran Keputusan Menteri Kehutanan No. 4795/Kpts11/2002.

Persetujuan kerjasama antara Indonesia dan Uni Eropa dalam Penegakan Hukum, Tata Kelola, serta Perdagangan Bidang Kehutanan atau Voluntary Partnership Agreement on Forest Law Enforcement Governance and Trade (FIEGT-VPA) ditandatangani pada September 2013 di Brussel (Belgia). FlEGTVPA bertujuan untuk menghentikan perdagangan kayu illegal dan memastikan hanya kayu dan produk kayu yang telah diverifikasi legalitasnya yang boleh di impor ke Uni Eropa oleh Indonesia. Indonesia adalah negara Asia pertama yang menandatangani
FlEGT-VPA dengan Uni Eropa, dan sejauh ini merupakan negara pengekspor kayu terbesar yang melakukan penandatanganan FlEGT-VPA. ${ }^{9}$

Persetujuan ini mencakup sistem sertifikasi atas kayu dan produk kayu yang diekspor dari Indonesia ke negara anggota Uni Eropa, berdasarkan Sistem Verifikasi Legalitas Kayu (selanjutnya disingkat SVLK) yang merupakan sistem penjaminan legalitas kayu Indonesia dan merupakan yang pertama di dunia yang pelaksanaannya sejalan dengan asasasas dalam FlEGT. Setelah diterbitkannya sertikat FlEGT, maka produk kayu Indonesia akan dinyatakan sudah memenuhi ketentuan Timber Regulation yang melarang penempatan maupun peredaran produk kayu illegal di pasar Uni Eropa. Para pelaku usaha di Uni Eropa pun tak perlu melakukan proses uji kelayakan terhadap kayu atau produk kayu yang telah bersertifikat FlEGT.

Dalam Pasal 3 ayat (1) FlEGT-VPA antara Uni Eropa dan Indonesia, di atur bahwa produk kayu dari dari indonesia yang dapat dikirim ke Uni Eropa adalah produk kayu yang berlisensi FlEGT. Begitu juga sebaliknya, Uni Eropa harus menerima produk kayu yang hanya yang telah berlisensi FlEGT. Definis lisensi FlEGT yang diberikan oleh Pasal 2 huruf e adalah dokumen keabsahan ( $V$-Legal) dari Indonesia yang menyatakan bahwa produk kayu tersebut legal.

Dalam Pasal 4 ayat 2 di atur bahwa otoritas yang berwenang mengeluarkan lisensi FlEGT wajib tidak menerbitkan lisensi FlEGT untuk setiap produk kayu yang terdiri dari, atau meliputi produk kayu yang diimpor ke lndonesia dari negara ketiga dalam bentuk yang dilarang untuk diekspor oleh hukum negara ketiga tersebut, atau apabila terdapat bukti bahwa produk kayu tersebut di produksi dengan melanggar hukum negara di mana tempat asal pohon produk kayu tersebut dipanen.

Indonesia berkewajiban untuk memverifikasi legalitas kayu yang diekspor ke pasar-pasar selain negara-negara Uni Eropa dan kayu yang diperdagangkan di pasar domestik dengan menggunakan SVLK. Hal tersebut sesuai dengan ketentuan yang ada dalam Pasal 10 ayat (1) FlEGTVPA.

Apabila dilihat dari ketentuan di atas, maka kemungkinan penyelundupan kayu illegal di Uni

\footnotetext{
${ }^{9}$ http://www.dephut.go.id/index.php/news/details/9367, diakses pada tanggal 21 Oktober 2013.
} 
eropa akan berkurang karena Indonesia berkewajiban untuk mengirimkan produk kayu yang legal. Artinya, kalau produk kayu yang dikirimkan oleh Indonesia ke Uni Eropa adalah produk kayu yang illegal, Uni Eropa berkewajiban untuk tidak menerima produk kayu tersebut memasuki pasar Uni Eropa. Kemungkinan penyelundupan kayu dari negara ketiga ke Indonesia juga berkurang karena lisensi tidak diberikan kepada produk kayu yang kayu tersebut diperoleh secara impor dan illegal. Dengan adanya F1EGT-VPA, pemerintah Indonesia dan Uni Eropa berharap akan berkurangnya penebangan atau pemanenan hutan secara illegal.

\section{Program Sertifikasi Oleh Lembaga Ekolabel Indonesia}

Adanya regulasi Eco Labelling atas produk kayu yang dikeluarkan oleh Uni Eropa, membuat produsen luar negeri yang akan mengimpor produk kayu ke negara-negara Uni Eropa harus tersertifikasi. Tidak terkecuali produsen asal Indonesia. Sehingga dengan ini, produsen Indonesia membutuhkan suatu lembaga yang mengeluarkan sertifikat Eco Label tersebut.

Saat ini, telah ada Lembaga Ekolabel Indonesia (selanjutnya disingkat LEI). LEI didirikan pada Tahun 1994, dipimpin oleh mantan Menteri Lingkungan Hidup RI, Emil Salim. Sifat kerja LEI independen dan tidak terikat oleh lembaga atau instansi pemerintah apapun. ${ }^{10}$

Semula, LEI adalah suatu badan hukum yang berbentuk yayasan. Setelah Oktober 2004, LEI mengubah bentuknya menjadi organisasi berbasis konstituen. LEI menjadi pemegang mandat para konstituennya, yang terdiri dari masyarakat adat, petani hutan, para pelaku bisnis seperti pemegang HPH/HTI, pengelola industri hasil hutan, pemerhati lingkungan, akademisi, dan para tokoh lingkungan. ${ }^{11}$

Sertifikasi Eco Label yang dilakukan oleh LEI ini biasa disebut sebagai sertifikasi LEI. Sertifikasi ini dilakukan untuk memberi nilai bahwa suatu produk merupakan hasil dari kegiatan pengelolaan hutan yang memperhatikan norma-norma lingkungan hidup, norma ekonomi dan norma sosial. Pada sertifikasi LEI, baik hutan maupun industri yang mengolah hasil

\footnotetext{
${ }^{10}$ http://www.dephut.go.id/Halaman/PDF/ECOLABELING. $p d f$, diakses pada tanggal 21 Oktober 2013.

${ }^{11}$ http://www.lei.or.id/id/tentang-sertifikasi-lei, diakses pada tanggal 20 Oktober 2013.
}

hutan perlu melalui proses sertifikasi apabila ingin menghasilkan produk kayu yang bersertifikat. Produk kayu yang telah lolos penilaian sertifikasi ditandai dengan adanya sertifikat dan label. Sistem sertifikasi yang dibangun oleh LEI bertujuan untuk mendorong perbaikan-perbaikan pengelolaan hutan di Indonesia melalui standar-standar yang dikembangkan. Dengan standar yang dikembangkan, sertifikasi diharapkan dapat mengembalikan jalur pengelolaan hutan dan memperbaiki kondisi pengelolaan hutan agar lebih baik. Logo LEI pada produk kayu memberikan jaminan bahwa keseluruhan produksi, mulai dari sumber bahan baku, hingga ke pengolahan akhir memenuhi nilai-nilai lingkungan, sosial, dan ekonomi. ${ }^{12}$

LEI menggunakan standar lokal namun telah diakui secara internasional seperti Perancis, Jerman, Belanda, Belgia, dan Amerika Serikat yang merupakan negara-negara potensial pasar kayu Indonesia. ${ }^{13}$

Keikutsertaan dalam program sertfikasi yang diadakan oleh LEI bersifat sukarela. Artinya para pengusaha produk kayu, tidak harus mengurus sertifikasi di LEI. Namun apabila para produsen tadi bersertifikat dan produknya diberikan Eco Label, tentu banyak dampak positif yang akan di dapat. Adanya Eco Labelling ini memiliki beberapa dampak positif baik untuk kelestarian alam, konsumen, maupun produsen itu sendiri. Bagi kelestarian alam, adanya sertifikasi ini menjadikan suatu alat untuk mencapai keseimbangan antara kepentingan ekonomi dengan perlindungan sumber daya alam khususnya hutan. Produsen dalam menghasilkan produk kayu, mau tidak mau harus dilakukan secara legal dan memperhatikan lingkungan agar ia memperoleh Eco Label. Sehingga dengan ini, akan menyelamatkan dan memperbaiki kondisi hutan di Indonesia saat ini.

Dari sisi konsumen, dengan adanya Eco Label ini, menjadikan adanya pilihan-pilihan produk kayu yang ramah lingkungan. Bagi konsumen yang peduli dengan lingkungan hidup tentu memiliki produk kayu yang diproses secara legal dan memperhatikan lingkungan.

12 http://www.lei.or.id/id/standar-sertifikasi-lei, dikases pada tanggal 20 Oktober 2013.

13 http://www.hukumonline.com/klinik/detail/cl3266/ pengaturan-ecolabelling-di-indonesia, diakses pada tanggal 21 Oktober 2013. 
Dari sisi produsen, Eco Label menjadi alat yang menunjukkan legalitas usahanya dan tanggung jawab moralnya terhadap lingkungan. Tentu bagi produsen yang produknya memiliki Eco Label bernilai lebih bagi konsumen dibandingkan dengan produk yang tidak bersertifikat Eco Label. Pada akhirnya akan timbul kepuasan bagi produsen karena telah dapat menembus pasar negara-negara yang sangat mengatur ketat terkait lingkungan, seperti di negara-negara Uni Eropa.

LEI tidak hanya memberikan sertifikat terhadap produk hasil hutan saja, namun hutannya sendiri apabila memenuhi kualifikasi tertentu juga diberikan sertifikat oleh LEI.

\section{Sertifikasi oleh Departemen Kehutanan}

Berbeda dengan Sertifikasi oleh LEI yang bersifat sukarela, sertifikasi oleh Departemen Kehutanan (selanjutnya disingkat Dephut) sifatnya adalah wajib. Sertifikasi ini dilakukan untuk mengetahui/mengevaluasi secara obyektif tingkat kepatuhan terhadap aturan main dan tingkat kinerja yang dicapai oleh para pemegang Hak Pengusahaan Hutan (HPH) dan/atau Ijin Usaha Pemanfaatan Hasil Hutan Kayu (IUPHHK), maka Departemen Kehutanan akan memberlakukan Program Penilaian Kinerja Pengelolaan Hutan Alam Produksi Lestari pada Unit Pengelolaan (yang juga dikenal sebagai Sertifikasi PHPL wajib) bagi seluruh pemegang Hak Pengusahaan Hutan dan/atau Ijin Usaha Pemanfaatan Hasil Hutan Kayu di Indonesia.

Program Penilaian Kinerja PHPL yang diberlakukan secara wajib tersebut merupakan bagian dari pelaksanaan tugas dan fungsi Dephut (regulasi, fasilitasi dan supervisi) di dalam pengusahaan hutan. Melalui program Penilaian Kinerja PHPL wajib ini, diharapkan akan dapat diperoleh data dan informasi tentang tingkat kepatuhan dan kinerja dari masingmasing pemegang Hak Pengusahaan Hutan dan/ atau Ijin Usaha Pemanfaatan Hasil Hutan Kayu sebagai bahan pertimbangan untuk menetapkan status Hak Pengusahaan Hutan dan/atau Ijin Usaha Pemanfaatan Hasil Hutan Kayu. ${ }^{14}$

Dephut juga memiliki program Sistem Verifikasi Legalitas Kayu (selanjutnya disingkat SVLK) sebagai sitem jaminan legalitas kayu. SVLK mulai diberlakukan pada tanggal 1 September 2009. SVLK ini memastikan apakah kayu yang dipasarkan diperoleh dengan cara yang legal. Kayu disebut legal jika memenuhi kebenaran asal kayu, ijin, Penebangan, sistem dan prosedur penebangan, administrasi dan dokumen angkutan, pengolahan, perdagangan atau pemindahtanganannya dapat dibuktikankan memenuhi semua persyaratan legal yang berlaku.

SVLK merupakan sistem pelacakan yang disusun secara multistakeholder untuk memastikan legalitas sumber kayu yang beredar dan diperdagangkan di Indonesia. Sistem verifikasi legalitas kayu diterapkan di Indonesia untuk memastikan agar semua produk kayu yang beredar dan diperdagangkan di Indonesia memiliki status legalitas yang meyakinkan. Konsumen di luar negeri pun tidak perlu lagi meragukan legalitas kayu yang berasal dari Indonesia. Unit manajemen hutan tidak khawatir hasil kayunya diragukan keabsahannya. Industri berbahan kayu yakin akan legalitas sumber bahan baku kayunya sehingga lebih mudah meyakinkan para pembelinya di luar negeri.

Komitmen Pemerintah dalam memerangi penebangan liar dan perdagangan kayu illegal merupakan perwujudan good forest governance menuju pengelolaan hutan lestari. Adanya permintaan atas jaminan legalitas kayu dalam bentuk sertifikasi dari pasar internasional, khususnya dari Uni Eropa, Amerika Serikat, Jepang dan Australia menjadikan SVLK ini sebagai bentuk National Insentive untuk mengantisipasi semakin maraknya permintaan skema sertifikasi legalitas kayu dari negara asing. SVLK diterapkan secara wajib atau mandatory untuk meningkatkan efisiensi pengelolaan hutan dan menjaga kredibilitas legalitas kayu dari Indonesia. Seperti halnya di atur dalam Peraturan Menteri Perdagangan No. 64 Tahun 2012 bahwa ada 40 jenis produk berbasis kayu 16 di antaranya per 1 Januari 2013 wajib memiliki sertifikat SVLK sedangkan 14 yang lainnya per 1 Januari 2012. Bagi unit manajemen yang telah mendapatkan sertifikasi lacak balak atau Chain of Custody/CoC, sertifikasi SVLK tetap wajib. ${ }^{15}$

${ }^{15}$ http://silk.dephut.go.id/index.php/info/vsvlk/3, diakses pada tanggal 22 Oktober 2013. 
Bagi kayu atau produk kayu yang telah memenuhi standar PHPL atau SVLK, maka akan diberikan logo yang disebut V-Legal. Pemenuhan standar PHPL atau SLVK dibuktikan dengan adanya sertifikat PHL (Pengelolaan Hutan Lestari) dan sertifikat VLK (Verifikasi Legalitas Kayu). Adanya V-Label di produk kayu ini sangat penting, karena di samping memang wajib ada, juga karena telah ditandatanganinya Voluntary Partnership Agreement on Forest Law Enforcement Governance and Trade (FlEGT-VPA) oleh Indonesia dan Uni Eropa. FlEGTVPA mengharuskan produk kayu dari Indonesia yang di ekspor ke Uni Eropa adalah hanya yang berlisensi FlEGT atau yang berlogo V-Legal. Produk yang tidak memiliki logo V-Legal, tidak dapat memasuki pasar Uni Eropa karena dianggap produk tadi tidak sah atau illegal.

Pada tahun 2006, Indonesia, dalam hal ini Kementerian Lingkungan Hidup, diterima sebagai anggota Global Ecolabelling Network (GEN) pada annual general meeting 2006 yang berlangsung di Seoul, Korea Selatan. Global Ecolabelling Network (GEN) merupakan asosiasi organisasi-organisasi ekolabel di seluruh dunia yang bersifat non-profit dan didirikan pada tahun 1994 dengan tujuan untuk meningkatkan, memajukan dan mengembangkan program ekolabel baik untuk produk maupun jasa. Melalui keanggotaan dalam $G E N$ ini program ekolabel Indonesia akan lebih dikenal luas secara internasional, selain itu dapat melakukan kerjasama secara langsung dengan anggota GEN lainnya dalam hal penetapan kriteria dan kesepakatan dalam proses sertifikasi yang dikenal sebagai mutual recognation. Selain itu sebagai anggota $G E N$, Indonesia dapat memperoleh akses informasi tentang perkembangan ekolabel dunia, dan apabila memungkinkan akan mendapat bantuan teknis untuk mengembangkan program ekolabel serta menghadiri rapat tahunan GEN (GEN annual meeting). ${ }^{16}$

\section{Sertifikasi oleh Asosiasi Pengusaha Hutan Indonesia (APHI)}

APHI atau Asosiasi Pengusaha Hutan Indonesia adalah suatu organisasi nasional perkumpulan para pengusaha hasil hutan di Indonesia. APHI sebagai

${ }^{16}$ http://www.menlh.go.id/indonesia-menjadi-anggotaglobal-ecolabelling-network-gen/, diakses pada tanggal 23 Oktober 2013. asosiasi bertanggungjawab atas kepentingan para anggotanya, yang antara lain akan diimplementasikan melalui program Sertifikasi Pernyataan Diri (Self Declare Certification) terhadap anggotanya untuk mengetahui intensitas kinerja PHPL yang telah dicapai. Melalui evaluasi intensitas kinerja PHPL terhadap masing-masing anggotanya tersebut, APHI akan menginformasikan posisi masingmasing anggotanya terhadap pencapaian PHPL dan memberikan rekomendasi yang diperlukan (melalui tim pakar yang dibentuk). Melalui program ini diharapkan APHI akan dapat mendorong kesiapan para anggotanya untuk menghadapi sertifikasi wajib dari Dephut maupun sertifikasi dari LEI yang keikutsertaannya bersifat sukarela. ${ }^{17}$

\section{PENUTUP}

\section{Kesimpulan}

Eco Labelling di Uni Eropa diatur dalam Council Regulation (EEC) No. 880 Tahun 1992, yang kemudian diubah dengan Regulation (EC) No. 1980 Tahun 2000. Tahun 2010 dibuatlah Regulation (EC) No. 66 Tahun 2010 yang juga mengatur mengenai Eco Labelling. Ada regulasi di Uni Eropa yang khusus mengatur mengenai kayu, yaitu Regulation (EU) No. 995 Tahun 2010 of the European Parliament and of the Council (EU Timber Regulation).

Dengan adanya globalisasi, maka aturan Eco Labelling yang ada di Uni Eropa tentu sangat berpengaruh bagi Indonesia. Oleh karenanya dibuatlah aturan hukum di Indonesia yang mengatur mengenai kriteria dan indikator pengelolaan hutan produksi lestari, yaitu Keputusan Menteri Kehutanan No. 4795/Kpts-II/2002 tentang Kriteria dan Indikator Pengelolaan Hutan Alam Produksi Lestari pada Unit Pengelolaan. Indonesia juga telah bekerjasama dengan Uni Eropa melalui Voluntary Partnership Agreement on Forest Law Enforcement Governance and Trade (FIEGT-VPA) untuk mencegah pemanenan hutan secara illegal dan perdagangan kayu secara illegal.

\section{Rekomendasi}

Perlu dilakukan pengawasan atas diberikannya V-Legal karena pemberian V-Legal merupakan pintu

${ }^{17}$ http://www.dephut.go.id/Halaman/STANDARDISASI_\&_ LINGKUNGAN KEHUTANAN/INFO V02/I V02.htm, diakses pada tanggal 22 Oktober 2013. 
masuk ekspor kayu dari Indonesia ke berbagai negara. Apabila negara tidak berhati-hati dalam memberikan V-Legal, maka tujuan pemberian V-Legal yang untuk upaya pengurangan penebangan liar tidak akan tercapai.

Indonesia perlu melakukan perjanjian pencegahan perdagangan kayu illegal seperti yang ada dalam Voluntary Partnership Agreement on Forest Law Enforcement Governance and Trade (F1EGT-VPA) agar penebangan hutan secara illegal di Indonesia dalam semakin berkurang.

\section{DAFTAR PUSTAKA}

\section{Peraturan Perundang-undangan:}

Voluntary Partnership Agreement on Forest Law Enforcement Governance and Trade (F1EGTVPA).

Keputusan Menteri Kehutanan No. 4795/Kpts-II/2002 tentang Kriteria dan Indikator Pengelolaan Hutan Alam Produksi Lestari pada Unit Pengelolaan.

Council Regulation (EEC) No. 880 Tahun 1992.

Regulation (EC) No. 1980 Tahun 2000.

Regulation (EC) No. 66 Tahun 2010.

Regulation (EU) No. 995/2010 of the European Parliament and of the Council (EU Ti m b e r Regulation).

\section{Buku:}

Hata, 2006, Perdagangan Internasional dalam Sistem GATT dan WTO (Aspek-aspek Hukum dan Non Hukum), Bandung: Refika Aditama.

Adolf, Huala, 2013, Hukum Perdagangan Internasional, Cetakan ke-5, Jakarta: Rajagrafindo.

Kurnia, Mahendra Putra, ed., 2011, Ketika Hukum Berhadapan dengan Globalisasi, Malang: UB Press.
Rosecrance, Richard, 1991, The Rise of the Trading State (Terjemahan Budiono Kusumohamidjojo dengan judul Kebangkitan Negara Dagang), Jakarta: Gramedia Pustaka Utama.

\section{Jurnal:}

Suminto, "Kajian Penerapan Ekolabel produk di Indonesia", Jurnal Standardisasi, Vol. 13, No. 3, Tahun 2011.

\section{Website:}

http://europa.eu/legislation_summaries/other/ l28020_en.htm, diakses pada tanggal 21 Oktober 2013.

http://ec.europa.eu/environment/forests/timber regulation.htm, diakses pada tanggal 21 Oktober 2013.

http://www.dephut.go.id/index.php/news/ details/9367, diakses pada tanggal 21 Oktober 2013.

http://www.dephut.go.id/Halaman/PDF/ ECOLABELING.pdf, diakses pada tanggal 21 Oktober 2013.

http://www.dephut.go.id/Halaman/ STANDARDISASI_\&_LINGKUNGAN_ KEHUTANAN/INFO_V02/I_V02.htm, diakses pada tanggal 21 Oktober 2013.

http://www.lei.or.id/id/tentang-sertifikasi-lei, diakses diakses pada tanggal 20 Oktober 2013.

http://www.hukumonline.com/klinik/detail/cl3266/ pengaturan-ecolabelling-di indonesia, diakses pada tanggal 21 Oktober 2013.

http://www.globalecolabelling.net/what_is ecolabelling/index.htm, diakses pada tanggal 23 Oktober 2013.

http://www.menlh.go.id/indonesia-menjadi-anggotaglobal-ecolabelling-network-gen/, diakses pada tanggal 23 Oktober 2013. 